\title{
Mensagem do Presidente da ABPol
}

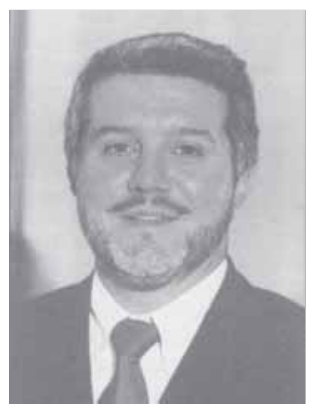

O ano de 2004, marcado pela transição política do país, avança rumo aos seus últimos meses com um quadro desafiante de dificuldades sociais e econômicas. Como o imobilismo jamais deve ser a opção diante das crises - frase do General de Gaule - a escolha da ABPol tem sido pelo dinamismo e pelo trabalho, refletidos nas suas múltiplas atividades. Nos primeiros seis meses do ano a nossa Associação esteve envolvida na realização de duas Reuniões das Comissões Técnicas em São Paulo, no "Café com Polímeros", no Rio de Janeiro - concebido pela ABPol Regional Leste, na organização do $8^{\circ}$. Seminário das Comissões Técnicas, em São Paulo, no oferecimento de um curso prático sobre "Análise de problemas em peças moldadas por injeção" e na divulgação de quatro módulos do Curso de Aperfeiçoamento em Tecnologia de Plásticos (UFSCar/DEMa/NRPP). Participou com "stand" no PlastShow Feira de Plásticos em São Paulo - e como convidada da Argenplás (Feira do Plástico da Argentina) e do Fórum Sul Brasileiro do Setor Plástico. As metas da ABPol de crescimento e visibilidade do primeiro semestre de 2004 foram cumpridas, mas não houve tempo para comemorações nem para férias... A agenda dos próximos meses contempla a realização do ISNAPOL ( $5^{\text {th }}$ International Symposium on Natural Polymers and Composite $8^{\text {th }}$ Brazilian Symposium on the Chemistry of Lignins and other Wood Components), em setembro, o V Encontro da Regional Leste, o apoio ao PPS 2004 e ao CBECIMAT, a participação na Feira K'2004, em Düsseldorf, três Reuniões das Comissões Técnicas, outros cinco módulos do Curso de Aperfeiçoamento em Tecnologia de Plásticos, além dos preparativos para o CBPol 2005 e o MACRO 2006. O intenso ritmo das atividades da ABPol acompanha de fato as pulsações e a dinâmica dos mercados e de algum modo a insere no cenário político-econômico do país, condição essencial para que a Associação cumpra com êxito o seu papel de disseminação e permeação do conhecimento técnico-científico e mercadológico do setor de polímeros por toda a sociedade brasileira.

Domingos Jafelice

\section{EDITORIAL}

Esta edição de Polímeros: Ciência e Tecnologia chega às mãos do pesquisador com 11 artigos técnico-científicos, cobrindo as áreas de Caracterização, Síntese, Blendas e Compósitos Poliméricos, Processamento e Modelagem de Reações de Polimerização.

A Seção Editorial apresenta o relato do Seminário das Comissões Técnicas de Reciclagem de Plásticos, Reologia e Processamento de Polímeros e Identificação e Caracterização de Polímeros. Reunindo em uma mesma edição resultados de pesquisa científica e temas de interesse tecnológico e mercadológico, nossa revista procura atender os interesses da comunidade acadêmica e industrial, promovendo a integração tão necessária entre a pesquisa básica e a pesquisa aplicada.

O crescente aumento no número de artigos submetidos e publicados, bem como a redução no tempo transcorrido entre a submissão e a publicação destes artigos, demonstra o dinamismo da comunidade e o reconhecimento de nossa revista como importante canal para divulgação da Ciência e Tecnologia de Polímeros. 